\title{
The Application of "News Teaching Mode" in Ideological and Political Theory Course Teaching in College
}

\author{
Wang Xiaofei \\ Hainan Medical College
}

Key words: Ideological and political theory; "News teaching" mode; Application

\begin{abstract}
News teaching mode" in Ideological and Theoretical Course teaching in college is mainly based on the characteristics of students learning to create the goal of "efficient", "useful", "interesting". Under the premise of theory union of Marxism theory and information effective communication, this pattern makes use of social hot spots to explore new ideological and political teaching mode. Good learning results have been achieved. This paper briefly introduces the combination theory of Ideological and political theory course teaching and "news teaching" form, and explains its application in practical teaching in detail.
\end{abstract}

\section{INTRODUCTION}

Stable teaching structure and framework are attained by continuous reflection on the basis of the teacher's long-term teaching experience.

These experiences are also known as teaching mode. Teaching mode is mainly to adapt to the teaching goal. News teaching mode mainly makes use of combination of social news and ideological and political theory courses to improve teaching methods and procedures and improve the actual effect of ideological and political teaching.

\section{THE THEORETICAL BASIS OF THE COMBINATION OF IDEOLOGICAL AND POLITICAL THEORY COURSE AND "NEWS TEACHING"}

\section{A. Practice principle of theory with practice}

Theory with practice takes the basic principle of Marxism as study guide. At the time of observation and analysis, take Marxism as the theory basis of major matters hotspot analysis at home and abroad. It is the basic Marxism principle, and also an important requirement for practical ideological line, which reflects that Marxist style study in colleges and universities ideological and political teaching practice is not static, but advances with the development of the Times. There are two main forms: one is to use indirect way to get, mainly news in the newspaper, Internet and television. The other is students' own personal experience, mainly around the students, and witnessed by students themselves. Make students get first-hand information effectively in the survey practice.

\section{B. Effective information transmission principle}

Effective information communication principle is a key principle in education and communication. When using this principle, it is mainly in teachers' effect and education link for students systematically in a planned way with a purpose. In the process of learning, achieve students' consensus and form the spread process of teacher feedback in time. Ideological and political theory course is mainly the ideological and political education information communication as the core of political opinions, ideas, and ethics, which mainly involves waiters, communicators, education media, information content, and feedback, etc. Both formed special education spread system. In the current mass media and the spread of Internet, it has become a key influence in people's ideological concept and value orientation. Large amounts of information in network channels reach every corner of society, so through efficient combination of principle of ideological and political education and the effectiveness of information to help students achieve the improvement of ideological awareness. 


\section{"NEWS TEACHING" MODE}

Teaching model's constituent elements are achieving conditions, activities, functions, and effect evaluation and so on, also including theoretical basis, principles, and other important parts. In ideological and political theory course teaching "news" mode, the important goal is to be "useful", "interesting" and "effective".

\section{A. The practice of teaching modes}

Study of teaching materials and collection of news materials are the main parts in the teaching of news. In addition, there are links like multimedia courseware development, the organization of classroom teaching, practice teaching arrangement, and teaching effect evaluation. The main equipment of implementation is multimedia classroom. Multimedia room conditions have an important influence on the presence as well as the effect of press material expression. Other auxiliary conditions are newspaper, Internet, TV, radio, etc., as long as it is news information sources, it can be used. In these media, Internet platform is the main extension of classroom teaching. In the process of teaching, classroom teaching cannot be taken only as a major category.

1. Collect news materials and study materials.

In the process of news teaching, the teacher must pay attention to the full tap of teaching material knowledge and the intersection of social news, realize the close ties of political theory and reality, teachers in teaching must mine textbook knowledge, and contact with social hot news. Because the related news stories are very rich, take mainly fresh news events occur in the student life cycle because these events are close to life, then they can more attract student's attention.

Socialist reforms and opening to the outside world, for instance, is the hot spots in "two sessions ". We should discuss them with political consultative system and people's congress system in our country.

2. Multimedia courseware design and teaching plans.

Under the premise of news material selection, design and processing, concept the organization of classroom teaching, select news teaching case, and elaborate the teaching courseware. News teaching cases, mainly including news show presence, design, and review three parts. Present forms mainly include text, video, images, etc, thus make the student in the aspect of political system architecture achieve a clear profound imagery. With news materials, inspire students to seek truth from facts, make students gradually realize the urgency and importance of their own learning, and realize the importance of ideological education.

For example, in order to let the students discuss both the properties and relationship between National People's Congress and political consultative conference, we present to students "two sessions" news. Why did the premier of the state council report to the National People's Congress (NPC)? What are the authorities of National People's Congress?

3. Teaching organization and interaction between teachers and students.

Classroom teaching organizations mainly are news comments, teachers guide teaching, news debate, and other forms. In accordance with the press teaching case, design the classroom teaching. News commentary includes three links: free speech, free primary review, and teacher summary. Freed speak involves 2 to 3 students, and one person for the main design. Because different students have different views, so teachers should encourage students talk from different angles, at the end of the classroom teaching, review. Teachers guide teaching is more common in classroom teaching, and news debate, which mainly preside by the teacher, display news materials, and arrange motion. There are also requirements for the students. The students after class carry out the preparation, and then debate in class, and teachers carry out the review.

4. Concrete teaching practice.

Concrete practice teaching refers to the students find news topic after class in accordance with the knowledge, and then writes the news comments. You can arrange three to four students every semester for news reporting activities. The main news topic is indirectly obtained in the network, teachers at the same time, encourage students in the discovery and observation of unearthed 
problems, from firsthand experience to carry out the report, get their own experience, and form their own unique evaluation.

5. Teaching evaluation.

After teaching, students' learning situation would be done. The main way is combining assessment and test. Class performance grade accounts for $40 \%$ in student's total score according to the actual performance scores points and students participation situation in class. Paper test purpose is to test if students can use the theory of textbook knowledge for the analysis of the problem, and expand ability. The direction of the exam is theory with practice.

6. Teaching effect feedback.

In the end of teaching, we should not only evaluate students' learning situation, but also carry on the feedback to the teacher's teaching situation. There are two main ways. The first kind is irregular, informal teaching way. The teachers' outside class time communication with students is conducive to timely feedback in students learning. It can not only promote the relationship between teachers and students, but in the process of chat, get lots of important information feedback. Second is regular form and relatively formal. At the end of the semester courses, through the scientific questionnaire survey form to students, the teachers' teaching can get timely improvement. This method is better to make up for the first way in implement to make feedback information more comprehensive and real.

\section{$B$. The problems need to pay attention to in "news" teaching mode}

"News teaching mode" in ideological and political theory practice makes some natural views of college students in ideological and political theory course change to a new understanding, and correct misconceptions. Adoption of "news teaching" makes students affirm on The Introduction to Mao Zedong Thought and the Theory of Chinese Characteristic Socialism gradually. The students improve their understanding of things in practical teaching and knowledge. In different ideological education textbook learning, learning interest and learning effect are improved. The most obvious is the "Ideological and Moral Cultivation and Legal Basis" learning situation.

Some students also reflect that the course is of the most realistic and the most practical value. It changes the view of traditional teaching, and improves the previous strong theoretical problem in ideological and political theory course. Some students believe that ideological and political theory can only be ideological propaganda and education. Students' psychological resistance is addressed, and psychological prejudices are changed. Students in "news model" through news phenomenon investigate the truth behind the news and discussion. Students have increased the sensitivity of news and social hot spots, and learning self-consciousness is enhanced. This, for the teacher, is a good phenomenon, and the teacher should develop the good habit of attention to the news in daily observation and reading.

\section{EXPERIENCE}

\section{A. Analysis of the concept.}

News teaching and "Situation and Policy" are by no means equal. Many students think it is good to use news mode in ideological and political theory course teaching. Make the current news in the teaching process a relatively independent teaching, and import in the classroom. For example, many teachers like to use ten minutes before class for the students to explain their views on news and current affairs, and promote students to debate these facts, encourage students to speak their own points of view. Under heated discussion atmosphere, quite a few students who are indifferent to the affairs of state also combine with the reality and serious review these cases. The enthusiasm of students increased in ideological education courses. The teacher should guide the student to use relevant theories to solve the problem in the process to avoid disconnectedness between news and books.

B. Change the traditional way of learning.

On the basis of traditional student inert break, implement the change of learning style. Change the traditional teaching; the students get passively "duck" learning, and teachers teach typical teaching 
methods. Allowing students to participate in class, improve the enthusiasm of class participation has important influence to news teaching and learning effect.

C. The use of information teaching means.

The continuous development of information technology, and the increase number of news related media platforms, such as network, radio, television, multimedia, etc., constructs a "threedimensional" teaching platform.

D. Cases design modular.

Such organization is most conducive to the theme strengthening, and more strengthened revealing.

E. Play the teachers' spirit of solidarity and collaboration.

In order to improve the teachers' higher enthusiasm in teaching, regularly select good news case, and choose the classic case of teaching.

F. Actively do extracurricular study.

To take the initiative to cooperate with the new situation of news teaching practice, teachers should actively carry out teaching reform and question in the teaching research, adapt to the news teaching big workload and multiple links. Strengthen cooperation, and implement issues together. Under the unity cooperation way of labor division, the news teaching mode is basically established. In this process, the teachers in a timely manner collect news materials, and pay attention to the accumulation at ordinary times.

\section{CONCLUSION}

Combine "news teaching" mode with ideological and political theory course. Compared to the general ideological education, there are common characteristic and different places. The main difference is on the teaching method. College ideological and political theory course "news teaching" has to adopt the new view, recognize the advantages and disadvantages, and pay attention to the news cases in the area of hysteresis control. For news case, update work is important to achieve the combination of ideological and political theory course teaching and "news" teaching mode.

\section{REFERENCES}

[1] Wang Xiaochun, Li Qunshan. Ideological and political theory course "news teaching" model [J]. Journal of Theory and Practice of Ideological and Political Education Research, 2010, 26 (4)

[2] Wang Xiaochun, Yang Xuelong. Teaching effectiveness survey and analysis in ideological and political theory course "news teaching" model [J]. Journal of Yichun Institute, 2010, 32 (11)

[3] Xu Yan. The application of press teaching mode in ideological and political theory course [J]. Journal of Theory, 2013, (17)

[4] Jiang Shuo. Innovation of ideological and political education under new media environment [J]. China Press, 2013, (4) 